\title{
IMPLEMENTASI PASAL 504-505 KUHP DAN PERDA NO. 2 TAHUN 2008 TERHADAP PEMBINAAN TUNAWISMA DI KOTA MAKASSAR
}

\author{
Oleh: Adriana Mustafa \\ E-mail:adriana.mustafa@uin-alauddin.ac.id \\ Fakultas Syariah dan Hukum UIN Alauddin Makassar
}

\begin{abstract}
The main problem in this research is regarding the application of Article 504-505 of the Criminal Code and Regional Regulation Number 2 of 2008 against the Homeless in Makassar City, then formulated into a sub-problem or research question, namely what factors cause the emergence of homelessness in Makassar City and how to apply Article 504 - 505 of the Criminal Code against the Homeless? This research uses qualitative field research. The results of this study indicate that the factors that cause the emergence of homelessness are Poverty Problems, Education Problems, Work Skills Problems and Social Cultural Problems and Social Cultural Problems Consisting of Low Self-Esteem, Surrender to Physical Conditions, Health Problems. The application of Articles 504 - 505 of the Criminal Code has been implemented but has not been maximized, so this effort is not optimal enough, this is what makes the homeless still carry out their activities for economic needs. The implication of the research is that the South Sulawesi Provincial Social Service Government is expected to collect data on the homeless who do not have a place to live, build rehabilitation homes or develop work skills. It is advisable for the Makassar City DPRD Government to strengthen the sanctions given to the homeless in accordance with Articles 504 - 505 of the Criminal Code and Regional Regulation Number 2 of 2008.
\end{abstract}

Keywords: Implementation; Article 504-505; Homeless Development.

\section{PENDAHULUAN}

Kemiskinan merupakan salah satu dampak dari belum konstisten dan belum terkordinasinya penanganan masalah-masalah sosial ekonomi yang ada. Di samping itu orientasi penanganan belum berdasarkan aspirasi dan kebutuhan masyarakat setempat serta pemanfaatan potensi lokal yang belum maksimal. Penyebabnya kemiskinan berasal dari intern (keterbatasan pendidikan, pengetahuan, akses kesehatan, kurang memiliki keterampilan memberdayakan potensi) dan ekstern (kebijakan pemerintah, bencana sosial dan alam yang terjadi). Maslah kemiskinan di Indonesia berdampak negatif terhadap meningkatnya arus urbanisasi dari daerah pendesaan ke kota-kota besar termasuk Kota Makassar unuk mendapatkan penghidupan yang lebih. Kemiskinan pada umumnya disebabkan oleh ketidakberdayaan seseorang pada usia 
kerja, serta sulitnya mendapatkan pekerjaan atau pemutusan hubungan kerja akibat krisis ekonomi yang berakibat terjadinya pengangguran. ${ }^{1}$

Terjadinya kemiskinan diantaranya disebabkan adanya pengangguran, terbatasnya lapangan kerja, terbatasnya keterampilan yang dapat dikembangkan, karena adanya pemutusan Hak kerja (PHK) sebagai dampak krisis ekonomi. Masalah pengemis merupakan fenomena sosial yang tidak bisa dihindari keberadaanya terutama di Kota Makassar. Secara fisik, pengemis juga berinteraksi dengan masyarakat di sekitarnya tetapi sesungguhnya mereka terisolasi karena tidak bisa mencapai fasilitas yang ada. Banyak orang yang sebenarnya masih dalam keadaan sehat memilih untuk mengemis/meminta-minta dampak dari meningkatnya pengemis adalah munculnya ketidak aturan sosial yang ditandai dengan ketidaknyamanan, ketertiban, serta menganggu keindahan kota.

Strategi bertahan hidup yang dilakukan oleh tunawisma disebabkan karena keterbatasan akses maupun pengaruh dari lingkungan sosialnya, sehingga tunawisma hanya dapat mempertahankan hidup dengan segala kekurangan dan keterbatasanketerbatasan yang dimiliki. Melakukan strategi dengan cara penghematan dan menyimpan uang di saku atau tas bawaan pada uang yang mereka peroleh dari bekerja sebagai pemulung atau meminta uang kepada masyarakat sebagai pengemis. Segala aktivitas yang dilakukan juga merupakan cara bagaimana mereka bertahan hidup dijalan.

Selama ini kebijakan yang diambil masih bersifat insidental, ketika ada kejadian baru diperhatikan. Justru sebaliknya mematikan perekonomian mereka. Selama ini kebijakan realitas anak jalanan atau anak dilantarkan merupakan masalah yang menjadi sorotan publik dan perlu mendapatkan perhatian pemerintah pusat dan daerah untuk menanggulanginya. Permasalahan sosial tersebut merupakan masalah politik yang mendesak untuk ditangani melalui suatu pendekatan pelayanan yang transparan dan akuntabel. ${ }^{2}$

Penyebab kemiskinan bisa datang dari aspek individu. Ia menjelaskan bahwa kemiskinan merupakan akibat dari rasa malas, rendahnya kemampuan untuk menanggapi persoalan disekitarnya. ${ }^{3}$ Selain itu, pendidikan yang rendah ternyata juga besar pengaruhnya terhadap masalah kemiskinan. Faktor kemiskinan merupakan alasan pertama orang- orang menggelandang di kota-kota besar. Untuk pemenuhan hidup tunawisma di Kota Makassar, umumnya tunawisma bekerja sebagai pemulung, penjual koran, pengemis, pengamen, dan tukang becak. Profesi-profesi tersebut merupakan salah satu strategi dalam bertahan hidup tunawisma, bahwa strategi bertahan hidup adalah sebagai rangkaian tindakan yang dipilih secara standar oleh individu dan rumah tangga yang miskin secara sosial ekonomi. Oleh karena itu

${ }^{1}$ Balai Besar Penelitian dan Pengembangan Pelayanan Kesejahteraan Sosial, Media Informasi Penelitian Kesejahteraan Sosial (Yogyakarta: Astha Media Grafika, 2005), h. 56

${ }^{2}$ Ronawaty Anasiru, Implementasi Model-Model kebijakan Penanggulangan Anak terlantar di Kota Makassar, hasil penelitian (Makassar, 2011), h. 176.

3Soetomo, Masalah Sosial dan Upaya Pemecahannya, (Yogyakarta: Pustaka Pelajar, 2008), h. 319. 
tunawisma dalam pemenuhan hidupnya hanya dapat bekerja sesuai dengan kemampuan sosial serta keterampilan yang dimilikinya. ${ }^{4}$

Menunjukkan bahwa mayoritas tunawisma takut terhadap kekerasan dan tidak mampu melindungi diri. Mereka juga frustasi dengan petugas penampungan dan reaksi negatif dari orang lain. Hal ini merefleksikan kebutuhan terhadap perawat yang memberikan perawatan yang holistik dan sensitif terhadap kebutuhan mereka secara kompeten. Harus diakui bahwa keberadaan pengemis, gelandangan, anak jalanan dan pengamen adalah masalah sosial, dan masalah ini adalah domain pemerintah, baik Pemerintah daerah, Pemerintah Kota, maupun Pemerintah Pusat serta tanggung jawab kita bersama. Pemerintah melalui Kementerian Sosial (Kemensos) sejatinya telah melakukan penanganan pengemis. Namun, lantaran sulit mendapat pekerjaan, pengemis yang telah diberi pembinaan itu kembali lagi harus mengemis. ${ }^{5}$

Untuk penanganan gepeng, fakir miskin, anak terlantar merupakan masalah yang harus dihadapi oleh semua pihak, dan bukan hanya pemerintah, orang tua atau keluarga, melainkan orang yang berada disekitarnya, mengenai masalah anak terlantar banyak hal yang sebenarnya diatasi, seperti adanya panti asuhan yang didirikan untuk menampung serta merawat mereka dan menangani akar masalah dari adanya anak terlantar. Tetapi kurangnya tenaga pelaksana dan minimnya dana yang diperoleh pelaksana, maka panti yang sudah berdiri tidak berfungsi dengan baik dan maksimal.

Penanggulangan gelandangan dan pengemis yang meliputi usaha-usaha preventif, represif, rehabilitatif bertujuan agar tidak terjadi pergelandangan dan pengemisan, serta mencegah meluasnya pengaruh akibat pergelandangan dan pengemisan di dalam masyarakat, dan memasyarakatkan kembali gelandangan dan pengemis menjadi anggota masyarakat yang menghayati harga diri, serta memungkinkan pengembangan para gelandangan dan pengemis untuk memiliki kembali kemampuan guna mencapai taraf hidup, kehidupan dan penghidupan yang layak sesuai dengan harkat martabat manusia. Usaha preventif dimaksudkan untuk mencegah timbulnya gelandangan dan pengemis di dalam masyarakat, yang ditujukan baik kepada perorangan maupun kelompok masyarakat yang diperkirakan menjadi sumber timbulnya gelandangan dan pengemis. Usaha represif dimaksudkan untuk mengurangi atau meniadakan gelandangan dan pengemis yang bertujuan baik kepada seseorang maupun kelompok orang yang disangka melakukan pergelandangan dan pengemisan. usaha represif sebagaimana dimaksud meliputi: razia, penampungan sementara untuk diseleksi, pelimpahan.

Dalam kehidupan nasional berideologi liberal, di mana banyak pikiran dihegemoni oleh keyakinan dasar bahwa manusia individu itu menurut kodratnya dikaruniai kemampuan rasional yang sama, kemiskinan dan nasib buruk lainnya bukanlah sekalikali kekeliruan sistem melainkan kesalahan individu itu sendiri. Pendidikan merupakan hal penting yang akan menjadi modal setiap orang dalam berbagai urusan terutama dalam mencari pekerjaan. Setiap lapangan pekerjaan pasti mempunyai

${ }^{4}$ Laily fu'adah, dkk., "Tindakan Sosial Tunawisma terhadap Strategi Bertahan Hidup di Kota Semarang", Journal of Education Social Studies 6, no. 1 (Universitas Negeri Semarang ,2017), h. 46.

5Irawati said, Analisi Problem Sosial (Makassar: Alauddin University Press, 2012), h. 47 
standar pendidikan atau sering kita sebut dengan minimal lulusan. Para gelandangan dan pengemis rata-rata tidak memiliki pendidikan yang cukup, bahkan tidak sedikit yang tidak pernah mengenyam bangku sekolah.

Tingkat pendidikan gelandangan dan pengemis yang relatif rendah menyebabkan kendala bagi mereka memperoleh pekerjaan yang layak untuk memenuhi kebutuhan pribadi maupun kebutuhan keluarga bagi yang sudah berkeluarga. Akhirnya hal ini pun berdampak kepada anak-anak mereka. Karena tidak bisa memiliki pekerjaan dan penghasilan yang cukup, mereka tidak mampu untuk meyekolahkan anaknya. Malahan banyak pula orang tua yang akhirnya menyuruh anaknya untuk menjadi pengamen maupun pengemis demi untuk membantu orang tuanya memenuhi kebutuhan keluarganya ${ }^{6}$.

Secara fisik, pengemis juga berinteraksi dengan masyarakat disekitarnya tetapi sesungguhnya mereka terisolasi karena tidak bisa mencapai fasilitas yang ada. Kebanyakan orang sebenarnya masih dalam keadaan sehat memilih untuk mengemis/meminta, hal ini dipengaruhi oleh faktor kemiskinan, terbatasnya lapangan pekerjaan yang tersedia, terbatasnya pengetahuan dan keterampilan, masalah urbanisasi serta masalah kecacatan.

Hukum dibuat mempunyai tujuan agar masyarakat menjadi makmur dan sejahtera. Dalam kehidupan bermasyarakat, perilaku individu atau kelompok sosial terikat dengan berbagai norma sosial atau hukum, baik yang tertulis mau pun tidak tertulis. Hukum di lahirkan bukan untuk hukum itu sendiri, tetapi untuk kepentingan dan mencapai kebahagiaan kehidupan manusia. ${ }^{7}$

Meski hukum telah dibuat oleh pemerintah tetapi jumlah kemiskinan tidak semakin berkurang dikarenakan krisis ekonomi. Krisis ekonomi yang menyebabkan penderitaan terutama bagi masyarakat perkotaan. Sebab krisis ekonomi terutama berdampak buruk bagi sektor industri yang banyak terpengaruh oleh ketidak stabilan rupiah terhadap mata uang asing. Pembangunan ekonomi yang tidak merata membuat daerah pendesaan sulit dans angat terbatas untuk mendapatkan lapangan pekerjaan.

Berbagai alasan menjadikan seseorang memilih untuk menjadi hidupnya sebagai seorang gelandangan ataupun pengemis. Mulai dari permasalahan psikologis, kerenggangan hubungan dengan orang tua, atau keinginan untuk hidup bebas. Namun alasan terbanyak dan paling umum adalah kegagalan para perantau mencari pekerjaan. Untuk bertahan hidup ditengah kehidupan Kota yang keras, anak-anak jalanan biasanya melakukan pekerjaan diberbagai pekerjaan di sektor informal, baik yang legal di mata hukum. Ada yang bekerja sebagai pedagang asongan dikereta api dan bus kota, menjajakan koran, menyamir sepatu, mencari barang bekas ataus ampah, mengemis dilampu merah, tukang lap mobil dan tidak jarang pula anak-anak jalanan yang terlibat pada jenis pekerjaan berbau kriminal seperti mencuri, bahkan menjadi bagian dari komplotan perampok.

${ }^{6}$ Jonathan Tribuwono, Implementasi Kebijakan Pembinaan Anak Jalanan, Gelandangan, Pengemis dan Pengamen Di Kota Makassar (Makassar, Fak: Ilmu Sosial dan Ilmu Politik Universitas Hasanuddin, 2017), h.2

${ }^{7}$ Umar Sholehudin, Hukum dan Keadilan (Malang Setara Press, 2011), hlm. 29 


\section{METODE PENELITIAN}

Penelitian ini menggunakan jenis penelitian lapangan (field Research) kualitatif, yaitu jenis penelitian yang di dalam proses memperoleh data penelitian langsung dari lapangan. Dengan diperkuat dengan hasil wawancara dan dokumentasi. Jenis pendekatan yang digunakan adalah menggunakan pendekatan Yuridis dan Sosiologis. Sumber data dalam penelitian terdapat dua sumber data yang digunakan yaitu sumber data primer berupa wawancara dan sumber data sekunder berupa hasil karya dan hasil penelitian, baik dalam bentuk buku, karya ilmiah, berupa skripsi, makalah, liputan dan jurnal-jurnal yang berkaitan dengan masalah yang diteliti. Metode pengumpulan data observasi, wawancara dan dokumentasi.

\section{HASIL \& PEMBAHASAN}

\section{Penerapan Pasal 504 dan pasal 505 KUHP terhadap Tunawisma}

Peraturan-peraturan hukum yang ada didalam negara Republik Indonesia mulai saat berdirinya negara Republik Indonesia merupakan suatu tertib hukum. Dalam Undang-Undang Dasar tahun 1945 amandemen ke 4, Pasal 34 Ayat (1) Menjelaskan bahwa fakir miskin dan anak terlantar dipelihara oleh negara. Dan ayat (2) yang berbunyi Negara mengembangkan sistim jaminan sosial bagi seluruh rakyat dan memberdayakan masyarakat yang lemah dan tidak mampu sesuai dengan martabat kemanusiaandan fasilitas pelayanan umum yang layak. Untuk melaksanakan tanggung jawab Negara Republik Indonesia diperlukan kebijakan pembangunan nasional yang berpihak pada fakir miskin dana anak terlantar secara terencana, terarah, dan berkenjutan. ${ }^{8}$

Di Indonesia sendiri sendiri masih belum begitu maksimal dalam penganan maslah gelandangan, pengemis dan anak terlantar. Sehingga masih banyak sekali kasus ketimpangan sosial yang terjadi yaitu bergelandangan dan meminta-minta yang dilakukan oleh orang dewasa, anak-anak dibawah umur dan lansia. Dan hal ini dilakukan karena kurangnya kebutuhan sehari-hari untuk mencukupi dirinya dan keluarganya

Dengan adanya keberadaan anak-anak terlantar, pengemis dan gelandangan menjadi ruang eksploitatif bagi preman yang mempunyai kekuasaan disuatu wilayah dimana anak-anak terlantar dan gelandangan pengemis menggantungkan nasib diwilayah tersebut. Selain itu, keberadaan mereka juga cenderung akrab dengan tindak kriminal, mereka juga rentan terkena virus, narkoba, free sex dan penyakit moral lainnya yang menghancurkan masa depan mereka. Tentunya, kita harus perhatikan akan kondisi tersebut, ditengah sistem kehidupan yangs emakin global, apa jadinya bila sebagian besar anak-anak indonesia khususnya tidak mengenyam pendidikan, tidak mendapatkan hak-haknya dan terus-terusan hidup dijalan untuk memenuhi kebutuhan dirinya dan keluarganya. Sehingga mereka terus berpindah-pindah dan tidur di tempat

${ }^{8}$ M.Yusuf, Delapan Langka Kreatif Tata Kelolah Pemerintah Dan pemerintah Daerah (Jakarta: Salemba Empat, 20011), h. 135. 
umum tanpa tempat tinggal yang layak dan jelas. Gelandangan dan pengemis juga rentan terhadap tindak kekerasan dan perlakuan salah. ${ }^{9}$

Selanjutnya di dalam Peraturan Pemerintah nomor 31 Tahun 1980 Tentang Penanggulangan Gekandangan dan Pengemis diatur bahwa gelandangan dan pengemis tidak sesuai dengan norma kehidupan bangsa Indonesia yang berdasarkan Pancasila dan UUD 1945, karena itu perlu diadakan usaha-usaha pembinaan. Usaha tersebut bertujuan untuk memberikan rehabilitasi kepada anak jalanan, gelandangan, pengemis dan pengamen agar ammpu mencapai taraf hidup, kehidupan dan penghidupan yang layak sebagai warga negara Republik Indonesia. ${ }^{10}$

Dalam penanganan pengemis, larangan untuk mengemis maupun menggelandang telah diatur di dalam pasal 504 dan pasal 505 Kitab Undang - Undang Hukum Pidana (KUHP) seperti Pasal 504 KUHP berbunyi Barang siapa mengemis di muka umum, diancam karena melakukan pengemis dengan pidana kurungan paling lama enam minggu. Dan Ayat berbunyi pengemisan yang dilakukan oleh tiga orang atau lebih yangt berumur diatas enam belas tahun, diancam dengan pidana kurungan paling lama tiga bulan. Sedangkan asal 505 KUHP berbunyi Barang siapa bergelnadangan tanpa pencarian, diancam karena melakukan pergelandangan dengan pidana paling lama tiga bulan. Dan dalam ayat berbunyi pergelandangan yang dilakukan oleh tiga orang atau lebih, berumur diatas enam belas tahun diancam dengan pidana kurungan paling laam enam bulan. ${ }^{11}$

Pasal diatas yang sering digunakan oleh polisi maupun Satpol Pamong Praja untuk melakukan razia penertiban terhadap para pengemis dan gelandangan serta anak-anak terlantar, dengan ini juga memberikan gambaran bahwa pemerintah dalam menangani perlindungan terhadap gelandangan, pengemis, fakir miskin anak terlantar belum maksimal dan tidak mau mengambil pusing untuk menanganinya. Begitu pula sebaliknya, Negara kuat tidak akan bertahan lama jika jika tidak mampu menciptakan kesejahteraan rakyatnya. ${ }^{12}$ Negara merupakan institusi atau lembaga politik yang merupakan manifestasi dari kebersamaan/kolektif sekelompok amnusia untuk mewujudkan kebaikan, kesejahteraan dankeadilan sosial bagi seluruh warganya. ${ }^{13}$

Berdasarkan ketentuan tersebut pengemis dikualifikasikan sebagai pelanggaran yang hukum hanya berupa pidana kurungan, pengemis dimuka umum berpotensi menimbulkan permasalahan sosial, diantaranya:

a. Masalah Lingkungan. Pengemisan pada umumnya tidak memiliki tempat tinggal tetap, tinggal di wilayah yang sebenarnya dilarang tetap tinggal,

9Penjelasan Umum PERDA No. 1 tahun 2014, Tentang Penanganan Gelandangan dan Pengemis 10Peraturan Pemerintah nomor 31 Tahun 1980 Tentang Penanggulangan Gelandangan dan pengemis ${ }^{11}$ Sri Risky Ayu, "Tinjauan Sosiologis Terhadap Pengemis yang Mengganggu Ketertiban Umum Perspektif Hukum Islam (Studi Kasus D Kota Makassar) (Makassar: Fak: Syariah dan Hukum,2017), h. 2

${ }^{12}$ Francis Fukuyama, State-Building: Governance and World Order in the 21st Century (Memperkuat Negara: Tata Pemerintahan dan Tata Dunia Abad 21) (jakarta: Gramedia terjemahan, 2005), h. 87.

${ }^{13 S y a r i f u d d i n ~ J u a r d i . ~ " I l m u ~ P o l i t i k ~ P r o f e t i k: ~ H i s t o r i s i t a s, ~ K o n t e k s t u a l i t a s ~ d a n ~ I n t e g r a s i ~ K e i l m u a n ~}$ dalam Ilmu Politik Kota Makassar" Laboratorium Ilmu Politik (Makassar UIN Alauddin, 2015), h. 194195. 
seperti: taman taman, bawah jembatan dan pinggiran kali. Oleh karena itu keberadaan mereka di kota besar sangat mengangu ketertiban umum, ketenangan masyarakat dan kebersihan serta keindahan kota.

b. Masalah kependudukan. Pengemis yang hidupnya berkeliaran di jalan dan tempat umum pada umumnya tidak memiliki kartu identitas (KTP/KK) yang tercatat di kelurahan (RT/RW) setempat. Selain itu sebagian besar dari mereka hidup bersama sebagai suami istri tanpa ikatan perkawinan yang sah sehingga menyulitkan pemerintah dalam melakukan pendataan kependudukan.

c. Masalah keamanan dan ketertiban. Maraknya pengemis di suatu wilayah dapat menimbulkan kerawanan sosial serta dapat menganggu kemanan dan ketertiban diwliyah tersebut.

d. Masalah Kriminalitas. Keberadaan pengemis yang sebagian besar memiliki tingkat ekonomi yang rendah dapat menjadi faktor yang menyebabkan mereka menghalalkan segala cara untuk dapat memenuhi segala kebutuhannya. Mulai dari pencurian, kekerasan dan lain sebagainya

Anak Jalanan sebagai salah satu permasalahan sosial tidaklah lepas dari peran pemerintah. Peran yang seharunya, yang memelihara itu bukan hanya pemerintah, peran yang seharusnya, yang memelihara itu bukan hanya pemerintah, tetapi juga DPRD sebagailembaga legislatif penentu kebijakan dalam undang-undang. Pemerintah menjalankan tugas pemeliharaan fakir, miskin, dan anak terlantar itu tergantung kepada apa yang diataur oleh undang-undang. Karena itu, yang pertama harus dipastikan adalah pengaturan dalam undang-undangnya harus benar-benar mencerminkan perintah konstitusi agar fakir miskin, dan anak terlantar dapat dipelihara dengan baik.14

Keberadaan tunawisma sebuah perkotaan menjadi salah satu masalah klasik yang dihadapi oleh pemerintah untuk mengurangi jumlah tunawisma, terkhusus di Kota Makassar, yang di sebabkan oleh berbagai hal, mulai dari permasalahan ekonomi hingga faktor kecacatan. Dinas Sosial Provinsi Sulawesi Selatan dan DPRD Kota Makassar merupakan lembaga yang bertanggung jawab terhadap tunawisma kemudian mendorong Pemerintah untuk mengeluarkan Pasal 504 - 505 KUHP dan Perda Nomor 2 tahun 2008 tetang Pembinaan Anak Jalanan, Gelandangan, Pengemis dan Pengamen yang dibuat dan dikeluarkan oleh Pemerintah Kota Makassar yang merupakan kebijakan publik, tindakan yang ditetapkan oleh pemerintah yang mempunyai tujuan tertentu demi kepentingan seluruh masyarakat.

Untuk mengetahui lebih lanjut peran Dinas Sosial dalam penerapan pasal 504-504 KUHP dan Perda nomor 2 tahun 2008 terhadap tunawisma, berikut hasil wawancara dengan pihak dinas sosial provinsi sulawesi selatan, Makfiran (30 tahun), berikut ini:

"Dinas Sosial dalam melaksanakan penerapan pasal 504-505 KUHP dan perda nomor 2 tahun 2008 dalam mengatasi pengemis dan gelandangan pemerintah melakukan tindakan rehabilitasi atau pembinaan terhadap tunawisma yang berkeliaran

14Jimly Asshiddiqie, Konstitusi Ekonomi (Jakarta: PT Kompas Media Nusantara, 2010), h. 288 
misalnya bimbingan keterampilan, bekerja dibengkel dan lain-lain. Setiap tahun pemerintah memberikan uang sebesar 5.000.000.00 (lima juta rupiah) per/orang"15

Hal yang sama juga diungkapkan oleh Muhammad Daenur (33 tahun)

"Pasal 504 dan 505 KUHP belum berjalan semaksimal mungkin dan tindakan pemerintah selama ini cuman melakukan rehabilitasi terhadap tunawisma, sebanyak 1.703 gelandangan dan 538 pengemis yang berada disulawesi selatan dan setiap pertahun meningkat. Jaminan hidup selama 3- 6 bulan dua puluh ribu per/kepala. Pembinaan melalui APBN (Anggaran Pendapatan dan Belanja Negara) dan APBD (Anggaran Pendapatan Belanja Daerah), tahun 2017 sudah terlaksana proker (program kerja) dimana proker itu mengadakan pembangunan rumah untuk tunawisma sebanyak 50 unit rumah di jeneponto karena kebanyakan tunawisma bersal dari jeneponto setelah itu diberikan keterampilan atau usaha dari UPTD (unit Pelayanan Tugas daerah)"16

Dari hasil wawancara, penulis dapat menyimpulkan bahwa, Pasal 504-505 KUHP belum berjalan semaksimal mungkin selama ini cuman melakukan rehabilitasi atau keterampilan. Pembinaan melalui APBN dan APBD sudah berjalan semaksimal mungkin, UPTD (Unit Pelayanan Tugas Daerah) sudah berjalan dari tahun 2017 sampai sekarang.

Hal yang disampaikan oleh Hj Sainal Dg. Beta (62 Tahun) yang ditemui di Kantor DPRD Kota Makassar, mengatakan:

"Penerapan Pasal 504 dan 505 KUHP sudah diterapkan tapi belum maksimal, penerapan tersebut melakukan rehabilitasi atau pembinaan, jadi undang-undang itu diterapkan kembali di peraturan daerah karena undang-undang itu ada yang tidak cocok di daerah kalau bercerita global, dan ada juga yang cocok. Perda di buat untuk melindungi tunawisma tersebut, selama pembuatan perda tuanwisma semakin berkurang ternyata ketahuan kebanyakan dari daerah lain yang diangkat dari Gowa, Makassar dan Jeneponto."17

Dari hasil wawancara dapat disimpulkan bahwa Penerapan Pasal 504 - 505 KUHP sudah di terapkan tapi belum maksimal, karena setiap kali tunawima ditangkap mereka mengulang kembali perbuatannya. Dengan adanya perda tunawisma diharapkan semakin berkurang tunawisma di pinggir jalan.

\section{Legal Opinion terhadap Perda Nomor 2 Tahun 2008 dalam Pembinaan Tunawisma}

Dalam Peraturan Daerah Nomor 2 Tahun 2008, Telah diatur secra rinci dan sangat jelas tentang langkah-langkah yang akan dilaksanakan oleh pemerintah daerah dalam memberikan pembinaan dan menangani masalah anak jalanan, gelandangan, pengemis

\footnotetext{
${ }^{15}$ Makfiran (30 tahun), Staf Dinas Sosial Provinsi Sulawesi Selatan "Wawancara" 19 September 2019, (jam 09:30-selesai)

16 Muhammad Daenur (33 tahun), Staf Dinas Sosial Provinsi Sulawesi Selatan "Wawancara" 19 September 2019, (jam 10:30-selesai)

${ }^{17} \mathrm{Hj}$ Sainal dg Beta (62 tahun), Anggota DPRD Kota Makassar "Wawancara" 22 Oktober 2019, (jam 14:20-selesai)
} 
dan pengamen yang semakin bertambah. Dalam menjalankan langkah-langkah pembinaan tersebut tentunya tidaklah berjalan dengan mudah sesuai dengan apa yang diharapkan sesuai dengan bait perbait dari perda tersebut. Namun di lain pihak Pemerintah Kota Makassar akan mendapatkan tantangan sebagai penghambat dari pembinaan yang dilakukan. ${ }^{18}$

Pembinaan juga adalah kegiatan yang dilaksanakan secara terencana dan terorganisir dengan maksud menekan, meniadakan, mengurangi dan mencegah luasnya anak jalanan dan pengamen jalanan untuk mewujudkan ketertiban umum. Pembinaan anak jalanan, gelandangan, pengemis dan pengamen dilakukan dengan tujuan untuk:

a. Memberikan perlindungan dan menciptkan ketertiban serta ketentraman masyarakat.

b. Menjunjung tinggi hak-hak asasi manusia serta harkat dan martabat sebagai warga negara yang harus dihormati

c. Menjaga sifat-sifat kekeluargaan melalui upaya musyawarah dalam mewujudkan kehidupan bersama yang tertib dan bermartabat

d. Menciptakan perlakuan yang adil dan proposional dalam mewujudkan kehidupan bermasyarakat.

e. Meningkatkan ketertiban dalam masyarakat melalui kepastian hukum yang dapat melindungi warga masyarakat agar dapat hidup tenang dan damai

f. Mewujudkan keseimbangan, keselarasan, keserasian antara kepentingan individu dan masyarakat dengan kepentingan bangsa dan negara.

Peraturan daerah ini tidak hanya mengatur pembinaan, tetapi juga mengatur pelarangan kepada masyrakat untyuk memberikan uang kepada para pengemis, Masyrakat akan diajak untuk terbiasa memberi atau menyumbangkan uang melalui lembaga-lembaga resmi. dalam peraturan daerah ini juga diatur sanksi bagi memberi uang kepada pengemis. Sanksi yang diberikan kepada pengemis dan gelandangan yang diatur dalam Perda No. 2 Tahun 2008 BAB VI Pasal 51 yaitu:

1. Pelanggaran atau Ketentuan pada Pasal 46 Peraturan Daerah ini akan dikenakan sanksi berupa denda/atau ancaman hukuman kurungan bagi gelandangan dan pengemis

2. Gelandangan dan pengemis sebagaimana dimaksud pada ayat (1) pasal ini, terdiri atas pengemis usia produktif 18-59 Tahun dan pengemis usia lanjut 60 Tahun ke atas

3. Pembinaan bagi gelandangan dan pengemis dapat dilakukan dengan cara interogasi, identifikasi, dan shock serta membuat perjanjian yang mengikat agar mereka tidak melakukan kegiatan mengemis dan/atau melakukan

\footnotetext{
${ }^{18}$ Siti Hajar, Peran PemerintahDalam Penanggulangan Maslah Sosial (Studi Kebijakan Publik Terhadap Peraturan Daerah Nomor 2 Tahun 2008 Pembinaan Anak Jalanan, Gelandangan, Pengemis dan pengamen Di Kota Makassar (Makassar: Fak: Ushuluddin Filsafat dan Politik UIN Alauddin Makassar, 2016), h. 60
} 
kegiatan ekonomi ditempat umum yang disaksikan oleh aparat dan/atau petugas dan perjanjian di maksud dapat dijadikan sebagai barang bukti di Pengadilan

4. Setiap gelandangan dan pengemis usia produktif sebagaimana dimaksud pada ayat (2) pasal ini ditemukan di tempat umum yang melakaukan kegiatan mengemis akan dikenakan hukuman pembinaan dalam panti rehabilitasi sosial selamna 10 (sepuluh) hari

5. Sanksi bagi gelandangan dan pengemis usia produktif sebagaimana dimaksud pada ayat (2) pasal ini, berupa:

a. Pembinaan dan pengendalian dilakukan untuk melakukan mereka agar tidak turun ketempat umum yang dilakukan oleh petugas

b. Pengambilan dapat dilakukan oleh petugas terhadap gelandangan dan pengemis yang melakukan aktivitas mengemis ditempat umum untuk selanjutnya rehabilitasi

c. Pengambilan dapat dilakukan oleh petugas terhadap gelandangan dan pengemis yang bersal dari daerah lain.

d. Bagi gelandangan dan pengemis yang telah memperoleh pembinaan sebagaimana dimaksud pada huruf a,b dan c kemudian selanjutnya masih didapati melakukan aktifitas mengemis akan diancam hukuman kurungan paling lama 3 (tiga) bulan atau denda paling banyak Rp. 5.000.000,- (lima juta rupiah).

6. Sanksi bagi gelandangan dan pengemis usia lanjut sebagaimana dimaksud ayat

(2) pasal ini, brupa

a. Pembinaan dengan cara menghalangi mereka agar tidak turun ke tempat umum yang dilkakukan oleh petugas

b. Pengambilan dapat dilakukan oleh terhadap gelandangan dan pengemis yang melakukan aktifitas mengemis di tempat umum untuk selanjutnya di rehabilitasi seumur hidup dalam sistem panti sosial (panti jompo)

Sanksi yang diberikan kepada pengemis dan gelandangan dilakukan berdasarkan acuan dari Perda No. 2 tahun 2008 BAB VI Pasal 51 di atas, sanksi tersebut telah di terapkan yang telah ditentuikan dalam Perda dalam menanggulangi pengemis yang ada di kecamatan panakukang. Upaya pemerintah untuk melakukann penanganan pengemis, jika dilihat dengan keadaan sekarang inin masih jauh dari konsep dan visi misi pemerintah. Kebijakan-kebijakan pemerintah yang dikeluarkan terkadang dianggap tidak pro dengan rakyat. Berkaitan dengan pengemis ada banyak peraturanperaturan dan kebijakan-kebijakan tentang ini, namun lebih berorientasi pada larangan-larangan mengemis ditempat umum, tapi bukan mengenai upaya-upaya dalam menangani masalah pengemis.

Pada kehidupan pengemis kemiskinan merupakan salah satu faktor seseorang menjadi pengemis karena kebanyakan alasannya adalah faktor ekonomi. Mereka mengemis demi untuk bertahan hidup dan untuk memenuhi kebutuhan sehari-hari mereka. Selain faktor ekonomi, kurangnya anggota badan atau cacat yang tidak tau 
harus bekerja apa untuk mempertahankan hidupnya sebisa mungkin menjadi pengemis, faktor umur dan kesehatan juga mendorong seseorang untuk menjadi pengemis karena beralasan bahwa tidak ada orang yang akan mempekerjakan orang yang sudah tua atau sakit-sakitan sementara untuk berobat tidak ada biaya jadi akhirnya menjadi pengemis untuk menutupi biaya hidup dan untuk berobat. Persoalan pengemis bukan hal yang baru, karena pemerintah sendiri telah memberikan perhatian khusus terhadap masalah pengemis. ${ }^{19}$

Gelandangan dan pengemis disebut sebagai salah satu penyakit sosial atau penyakit masyarakt (patologi sosial). Segala bentuk sosial yang dianggap tidak sesuai, melanggar norma-norma, adat istiadat, hukum formal, atau yidak bisa diintegrasikan dalam pola tingkah laku umum dikategorikan sebagai penyakit sosial atau penyakit masyarakat. Gelandangan dan pengemis hidup dengan serba keterbatasan, cenderung bergantung pada belas kasihan atau pemberian orang lain, berkeliaran di tempattempat umum seperti pasar, terminal, stasium dan perempatan jalan yang mana keberadaanya dalam kehidupan masyarakat dirasa sangatlah menganggu dan meresahkan.

Ada berbagai alasan mengapa seseorang menjadi Tunawisma, faktor penyebab diuraikan sebagai berikut:

\section{a. Masalah Kemiskinan}

Kemiskinan dapat memaksa seseorang menjadi mengemis sebagai pekerjaan. Hal ini seperti yang diungkapkan Radit (15 Tahun) merupakan pengemis yang berasal Jeneponto yang merantau di Makassar, mengungkapkan identitas diri dapat diketahui berdasarkan hasil wawancara sebagai berikut: "Saya asalnya dari Jeneponto, saya mengemis sekitar satu tahun, dulu saya berpindah-pindah tempat mengemis, sekarang mengemis di sekitaran Kampus II UIN Alauddin Makassar, mulai jam 7 pagi sampai jam 5 sore, mengapa saya mengemis saya ingin membantu ibu saya berjualan tissu sekaligus mengemis di depan mahasiswa, saya tidak malu mengemis karena yang saya lakukan perbuatan halal bukan mencuri" 20

Dari hasil wawancara di atas penulis dapat menyimpulkan bahwa pengemis di Kampus II UIN Alauddin Makassar ada yang berasal dari Jeneponto, yang melakukan kegiatan mengemis selama satu tahun masih peduli kepada orang tuanya untuk membantu berjualan dan masih ada mahasiswa yang memberikan uang kepadanya.

Pertanyaan ini juga sama dengan yang dikemukakan oleh Danur (14 tahun), yang di temui jalan Sultan Alauddin, berikut petikan wawancaranya: "Saya dari Bantaeng, saya lima tahun mengemis di Makassar, tempat mengemis saya di Jalan Sultan Alauddin, saya keluar mengemis jam 8 pagi dan pulang kalau sudah siang, tidak ada yang suruh saya

\footnotetext{
${ }^{19}$ Ira Soraya, "Peran Dinas Sosial Kota Makassar Dalam Penanganan Pengemis Di Keacamatan Panakkukang Kota Makassar" (Makassar: Fak. Dakwah dan Komunikasi UIN Alauddin Makassar, 2017), h. 43.

${ }^{20}$ Radit (15 tahun) Pengemis yang berada di Kampus II UIN Alauddin makassar "Wawancara", 15 Oktober 2019. (jam 14:30-selesai).
} 
mengemis, saya yang mau sendiri, biasanya kalau mengemis ada saya dapat uang 20 sampai 50.21

Berdasarkan beberapa hasil wawancara di atas penulis menyimpulkan bahwa kemiskinan yang menjadi faktor utama yang mendorong seseorang untuk mengemis.

\section{b. Masalah pendidikan}

Tingkat pendidikan pengemis relatif rendah sehingga mejadi kendala bagi mereka untuk memperoleh pekerjaan yang layak Seperti yang jelaskan oleh Suriani (40 tahun) yang ditemui kampus II UIN Alauddin Makassar, berikut wawancaranya: "Sudah menjadi pekerjaan sehari-hari saya, sudah tujuh tahun saya mengemis di sini, saya orang miskin perlu biaya buat hidup tidak punya sekolah. Saya tidak punya pekerjaan, keluarga tidak ada, kalau saya tidak mengemis tidak ada uang beli makanan dan bayar uang kos, kalau hasil mengemis 35rb satu hari mulai jam 8 sampai sore mengemis. ${ }^{22}$ Berdasarkan beberapa hasil wawancara di atas dapat disimpulkan bahwa pendidikan memiliki peran penting dalam kehidupan seseorang yang mendorong untuk mengemis demi melanjutkan kehidupan

\section{c. Masalah Keterampilan Kerja}

Pada umumnya pengemis tidak memiliki keterampilan yang sesuai dengan tuntunan pasar kerja. Hal ini seperti yang diungkapkan oleh Resuna (65 tahun) yang ditemukan di jalan heartasning, berikut wawancaranya: "Asal saya dari bone, saya mengemis sudah delapan tahun di Makassar, keluarga saya tidak ada, saya tidak mempunyai keterampilan apaapa, demi bertahan hidup terpaksa saya mengemis jadi pekerjaan sehari-hari untuk bisa menghidupi diri sendiri, pengahasilan yang saya dapatkan kadang 50rb, itupun tidak cukup untuk keperluan. ${ }^{23}$ Berdasarkan hasil wawancara di atas penulis menyimpulkan bahwa keterampilan sangat penting dalam kehidupan, karena keterampilan satu modal atau usaha yang bisa membuat sesuatu demi melanjutkan kehidupan:

\section{d. Masalah Sosial Budaya}

Ada beberapa faktor sosial budaya yang mempengaruhi menjadi tunawisma, yaitu:

1) Rendahnya harga diri

Rendahnya harga diri kepada sekelompok orang, mengakibatkan mereka tidak merasa malu untuk meminta-minta. Hal yang disampaikan oleh Suriani (40 tahun), yang ditemui di kampus II UIN Alauddin Makassar yang mengatakan bahwa: “Awal mengemis saya merasa malu, tapi karena sudah terbiasa rasa malu saya sudah tidak

\footnotetext{
${ }^{21}$ Danur (14 tahun) Tunawisma yang berda di jalan Sultan Alauddin "Wawancara" 10 September 2019 (jam16:45)

22Suriani (40 tahun) tunawisma yang berada di Kampus II UIN Alauddin Makassar “Wawancara" 11 Oktober 2019. (jam 10:30-selesai).

${ }^{23}$ Resuna (65 tahun) tunawisma yang berada di jalan Heartasning "Wawancara" 10 September 2019 ( jam 12: 45-selesai)
} 
ada, untuk menghidupi diri sendiri mengemis menjadi mata pencaharianku. ${ }^{24}$ Berdasarkan beberapa hasil wawancara di atas penulis menyimpulkan bahwa hilangnya rasa malu pada diri seseorang yang membuat terus menerus melakukan aktivitasnya sebagai pengemis

2) Pasrah terhadap kondisi fisik

Setiap manusia di lahirkan dengan berbagai kelebihan dan kekurangan. Tidak sedikit manusia terlahir dengan sempurna. Hal ini yang membuat kesempatan bersekolah dan kerja menjadi terbatas karena lapangan pekerjaan. Sehingga akhirnya orang-orang penyandang cacat banyak yang tidak tau pekerjaan apa yang pantas untuk di pekerjakan buat penyadang cacat, sehingga mereka memilih menjadi tunawisma. Hal ini seperti yang di sampaikan oleh Dimas (12 tahun) yang ditemui didepan masjid di jalan Kacong dg. Lalang, berikut wawancaranya: "Asal saya dari Bantaeng, kerjaan saya pemulung sekaligus meminta-minta, karena kecelakaan saya tidak tahu pekerjaan apa yang saya lakukan kalau bukan mengemis, saya sudah tiga tahun jadi seorang pengemis. ${ }^{25}$ Dapat disimpulkan bahwa hasil wawancara diatas bahwa pasrah kondisi fisik membuat seseorang susah mencari pekerjaan sehingga untuk melanjutkan kehidupan dengan cara mengemis

\section{e. Masalah Kesehatan}

Dari segi kesehatan pengemis termasuk kategori warga negara dengan tingkat kesehatan yang rendah akibat rendahnya gizi makanan dan keterbatasan akses pelayanan kesehatan. Pernyataan ini juga sama dengan yang diungkapkan oleh Suriani (40 tahun) yang ditemui di Kampus II UIN Alauddin Makassar, berikut wawancaranya: "Saya mengemis untuk makan saja, saya sering sakit-sakitan dan tidak menerima kartu KIS (Kartu Indonesia Sehat) dan saya tidak menentu penghasilan yang saya dapat perhari" 26

Sama halnya yang dikatakan oleh Resuna (65 tahun) waktu wawancara: "Saya selama di makassar susah mendapatkan pekerjaan terpaksa saya mengemis jalan satusatunya untuk menghidupi kebutuhan saya, saya sering sakit-sakitan" ${ }^{27}$ Berdasarkan hasil wawancara di atas dapat disimpulkan bahwa faktor yang menyebabkan seseorang menjadi tunawisma adalah kemiskinan, pendidikan, keterampilan kerja dan faktor kecacatan, hal ini merupakan alasan yang klasik bahwa alasan tersebut merupakan faktor utama yang diungkapkan informan dalam wawancara.

\footnotetext{
${ }^{24}$ Suriani (40 tahun) tunawisma di Kampus II UIN Alauddin Makassar "Wawancara" 11 Oktober 2019 (jam 10:30-selesai)

${ }^{25}$ Dimas (12 tahun) Tunawisma di Jalan Kacong dg. Lalang "Wawancara" 25 September 2019 (jam 14:30)

${ }^{26}$ Suriani (40 Tahun) Tunawisma di kampus II UIN Alauddin Makassar "Wawancara" 11 Oktober 2019 (jam 10:30-selesai)

${ }^{27}$ Resuna (65 tahun) Tunawisma di Jalan Heartasning “Wawancara” 25 Oktober 2019 (jam 12:45)
} 


\section{KESIMPULAN}

Penerapan Pasal 504 - 505 KUHP sudah diterapkan tapi belum maksimal, sehingga usaha ini belum cukup optimal hal ini membuat tunawisma masih tetap melakukan aktivitasnya demi kebutuhan ekonomi. Rehabilitasi atau pembinaan yang dilakukan oleh Dinas Sosial untuk mengurangi tunawisma diterapkan kembali di peraturan daerah karena Undang-undang tersebut ada yang tidak cocok di daerah. Untuk menunjang keberhasilan, melalui Dinas Sosial Provinsi Sulawesi Selatan melakukan kerja sama dengan Satpol PP, dan Kepolisian. Faktor yang mempengaruhi sehingga munculnya tunawisma yaitu masalah kemiskinan, masalah pendidikan, masalah keterampilan kerja dan masalah sosial budaya. Kemiskinan faktor utama mendorong seseorang untuk tunawisma sehingga pendidikan menjadi terhambat dan keterampilan kerja jadi susah untuk mencari pekerjaan dan sosial budaya yang mempengaruhi tunawisma. Implikasi dari penelitian diharapkan Pemerintah Dinas Sosial Provinsi Sulawesi Selatan melakukan Pendataan terhadap terhadap Tunawisma yang tidak mempunyai tempat tinggal, membangun panti rehabilitasi atau pembinaan keterampilan kerja. Sebaiknya Pemerintah DPRD Kota Makassar mempertegas sanksi yang diberikan kepada Tunawisma sesuai dengan Pasal 504 - 505 KUHP dan Perda Nomor 2 tahun 2008.

\section{DAFTAR PUSTAKA}

\section{Buku:}

Asshidiqie, Jimly. Konstitusi Ekonomi. Jakarta: PT. Kompas Media Nusantara, 2010.

Ayu, Sri Risky. "Tinjauan Sosiologi terhadap Pengemis yang Mengganggu Ketertiban Umum Perspektif Hukum Islam (Studi Kasus di Kota Makassar)" Makassar: Fakultas Syari'ah dan Hukum UIN Alauddin, 2017.

Balai Besar Penelitian dan Pengembangan Pelayanan Kesejahteraan Sosial. Media Informasi Penelitian Kesejahteraan Sosial. Yogyakarta: Astha Media Grafika, 2005.

Dillah, Suratman Philips. Metode Penelitian Hukum. Bandung: Alfabeta CV, 2014.

Fukuyama, Francis. State - Building: Governance and World Order in the 21st Century (Memperkuat Negara: Tata Pemerintahan dan Tata Dunia Abad 21). Jakarta: Gramedia Terjemahan, 2005.

Hajar, Siti. "Peran Pemerintah dalam Penanggulangan Masalah Sosial (Studi Kebijakan Politik terhadap Peraturan Dearah Nomor 2 Tahun 2008 Pembinaan Anak Jalanan, Gelandangan, Pengemis dan Pengamen di Kota Makassar" Makassar: Fakultas Ushuluddin Filsafat dan Politik UIN Alauddin Makassar, 2016.

Juardi, Syarifuddin. Ilmu Politik Profetik Historisitas, Kontekstual dan Integrasi Keilmuan dalam Politik. Makassar: Lab. Politik UIN Alauddin Makassar, 2015.

Poerwadarminto, WJS. Kamus Besar Bahasa Indonesia. Jakarta: Balai Pustaka, 1990.

Said, Irawati. Analisis Problem Sosial. Cet. I; Makassar: Alauddin University Press, 2012. Soedjono, Pengemis Berkeliaran di Ibu Kota. Cet. I; Jakarta: Tempo, 1993. 
Soraya, Ira. "Peran Dinas Sosial Kota Makassar dalam Penanganan Pengemis di Kecamatan Panakkukang Kota Makassar". Makassar: Fakultas Dakwah dan Komunikasi UIN Alauddin, 2017.

Soetono, Masalah Sosial dan Upaya Pemecahannya. Cet. I; Yogyakarta: Pustaka Pelajar, 2008.

Sugiyono. Metode Penelitian Kuantitatif, Kualitatif dan R \& D. Cet. 19; Bandung: Alfabeta CV, 2013.

Suryana, Effendi. Pancasila dan Ketuhanan Jati Diri Bangsa. Cet. I; Bandung: PT. Rafika Aditama, 2015.

Tribuwono, Jonathan. "Implemantasi Kebijakan Pembinaan Anak Jalanan, Gelandangan, Pengemis dan Pengamen di Kota Makassar". Makassar: Fakultas Ilmu Sosial dan Ilmu Politik Universitas Hasanuddin, 2017.

Twikromo, Y. Argo. "Gelandangan Yogyakarta Suatu Kehidupan dalam Bingkai Tatanan Sosial-Budaya “Resmi”. Yogyakarta: Universitas Atma Jaya, 1999.

Universitas Islam Negeri Alauddin Makassar. Pedoman Penulisan Karya Tulis Ilmiah: Makalah, Skripsi, Disertasi dan Laporan Penelitian. Makassar: Alauddin Press, 2013.

Wignjosoebroto, Soetandyo. Hukum dalam Masyarakat. Cet. I; Yogyakarta: Graha Ilmu, 2013.

Wirosardjono, Soetjipto. Gelandangan dan Pilihan Kebiijakan Penanggulangan. Jakarta: LP3E, 1998.

Yafie, Alie. Islam dan Problem Kemiskinan. Jakarta: Pesantren P3M, 1986.

Yusuf, M. Delapan Langkah Kreatif Tata Kelola Pemerintah dan Pemerintah Daerah. Jakarta: Selemba Empat, 2011.

\section{Peraturan Perundang-Undangan:}

Undang-Undang Dasar Negara Republik Indonesia Tahun 1945.

Undang-Undang Nomor 1 Tahun 1946 tentang KUHP.

Peraturan Pemerintah Nomor 31 Tahun 1980 tentang Penanggulangan Gelandangan dan Kemiskinan.

Penjelasan Umum PERDA No. 1 Tahun 2004 tentang Penanganan Gelandangan dan Pengemis.

Peraturan Kepala Kepolisian RI No. 14 Tahun 2007 tentang Penanganan Gelandangan dan Pengemis.

Peraturan Daerah Kota Makassar Nomor 2 Tahun 2008 tentang Pembinaan Anak Jalanan, Gelandangan, Pengemis dan Pengamen di Kota Makassar.

\section{Jurnal dan Publikasi Ilmiah:}

Ahmad, Maghfur. "Strategi Hidup Gelandangan dan Pengemis (Gepeng)". Jurnal Ilmiah 7, no. 2 (2010): h. 2-10.

Anasiru, Ronawaty. "Implementasi Model-Model Kebijakan Penanggulangan Anak terlantar di Kota Makassar". Laporan Hasil Penelitian (Makassar, 2011), h. 176

Fu'adah, Laily. "Tindakan Sosial Tunawisma terhadap Strategi Bertahan Hidup di Kota Semarang". Journal of Education Social Studies. Semarang, 2017. 


\section{Internet/Website:}

https://blogspot.bambangrustanto.html pengertian Tunawisma atau pengemis. Diakses pada tanggal 25 September 2019.

Penyandang Masalah Kesejahteraan Sosial, www.policy.hu/suharto/modula/makindo40.hm. diakses pada tanggal 15 Agustus 2019. 